for the activity. Changing the flavanone hesperidine into the corresponding flavonole entails inactivation.

The therapeutic effects observed after the administration of 'citrin' in man in septic conditions, also accompanied by polyarthritis and endocarditis, suggest that the age-old beneficial effect of fruit juice is partly due to its vitamin $\mathbf{P}$ content.

This research is being sponsored by the Josiah Macy Jr. Foundation, New York.
A. Benthósth.
ST. RUSZNYÁK.
A. SZENT-GYÖRGYI.

Institute for Medical Chemistry and Medical Clinic,

Szeged. Dec. 23.

' NATURE, 138, 798 (Nov. 7, 1936).

\section{Plant Collecting on the Pribilof and Aleutian Islands, I936}

THE Aleutian Islands stretch from the tip of the Kenai Peninsula of Alaska for 1,200 miles westwards to Kamchatka. They comprise some fifteen larger islands and hundreds of smaller ones, and owing to their inaccessibility have been very little explored botanically.

The Swedish botanist of Kamchatka, Dr. Erik Hulten, of the University of Lund, made important observations on the Aleutian isles in 1932. I visited them last summer, through the courtesy of the United States Government (to which they belong), and was also allowed to spend some days and make a botanical collection for the British Museum (Natural History) on the prohibited fur-seal islands of the Pribilofs, about 150 miles north of the Aleutians.

Unalaska village, near Dutch Harbour, was my base for botanical work in the Aleutians. I reached it from Seward, in Alaska, in mid-July by a small monthly steamer, the Starr. Owing to delay en route I was able to spend some time collecting at Seward, and two weeks on the very interesting and fertile island of Kodiak, off the Kenai Peninsula. During the eruption of Katmai in 1913, the north-east portion of Kodiak lay for long under a thick covering of ash which killed all vegetation for a year or two.

At Unalaska I collected during part of July and early August, and made a collection of about 318 specimens. The island is very fertile, vegetation growing up to the summits of many of the mountains of several thousand feet, but owing to the dense vegetation and entire lack of roads it is very difficult in summer to get far afield, as there is no means of transport. Finding the further islands quite inaccessible without the aid of the United States coastguard vessels (which were in 1936 the only ones calling there once or occasionally twice in the season), I applied to the Department of the Interior at Washington, and was granted permission to make the last trip of the season, in August (unfortunately late for botanical work) so far west as Attu, the last of the islands, on the United States Coastguard Cutter Chelan, which was doing hydrographic survey work in these uncharted waters. Unfortunately, landings were usually brief, but on Attu (where a precarious landing of a few hours was all that was possible owing to bad weather conditions) I was granted the help of two sailors of the Chelan in collecting the plants, and obtained some seventy specimens, including a few Asiatic species not gathered on the other islands. Landings of two days were made at
Kiska (where some fifty to sixty species were gathered), an interesting volcanic island, now a prohibited shore to aliens as it is a U.S. naval reserve, and at Amchitka and Atka.

In all, some 2,000 specimens were gathered on the Kenai Peninsula and the Aleutians, including about 160 species from the Pribilof Islands. Many thanks are due to the personnel of the U.S.S. Chelan and the coastguard authorities at Unalaska for their kind assistance, and to the agent of the U.S. Government and the Bureau of Fisheries on the Pribilof Isles, for much valuable assistance in transport and collecting.

British Museum (Natural History), IsOBEL W. HuTCHISON. London, S.W.7.

An Amphipod, Eucrangonyx gracilis S. I. Smith, new to Britain

RECENT exhaustive investigations into the fauna of filtration plants, which are being conducted by the Water Examination Department of the Metropolitan Water Board, under the direction of Colonel C. H. H. Harold, have resulted in the discovery at the Lea Bridge Waterworks of Eucrangonyx gracilis S. I. Smith. This species has been recorded only from Canada and the United States. It was collected in October and November 1936 by Mr. A. C. Gardiner, from whom $I$ obtained the following notes on its distribution in the filters and its appearance in life. Specimens were submitted for identification to Prof. A. Schellenberg, of Berlin, to whom my thanks are due.

The majority of specimens were found in culverts below the filter beds at the Lea Bridge Works : these culverts are in complete darkness, and specimens from them were whitish in colour, though with welldeveloped black eyes. A few were found among weeds on the grating of the intake to these filters, together with Asellus aquaticus (which was also found in the subterranean culverts) and Gammarus pulex. These specimens were of a quite dark slatyblue colour. It was not ascertained whether this species was present in the River Lea, from which these filter beds are supplied with water. It is even possible that it is widely distributed in England. In Canada and the United States it has been recorded from a large number of loci, chiefly in surface waters. A list of these can be found in Shoemaker.

Eucrangonyx can be distinguished from Gammarus by the absence of spines on the dorsal surface of the urosome : from Niphargus by the presence of welldeveloped black eyes and from Crangonyx by the presence of a small inner ramus to uropod III. $E$. gracilis can usually be distinguished in life from Gammarus pulex by its smaller size. Stebbing ${ }^{2}$ gives a detailed description of this species. The only published figure of the whole animal is that of $\mathrm{Kunkel}^{3}$, which is crude and in some respects incorrect. Various features are figured by Weckel*, Huntsman ${ }^{6}$ and Shoemaker ${ }^{1}$. Weckel's figures are inferior to those of Huntsman and Shoemaker.

Department of Zoology, G. I. CRAwFord. British Museum (Natural History).

$$
\text { Jan. } 15 .
$$

' Shoemaker, C. R.,Amer. Mus.Novitates, 598, 15, fig. 9, $a$ and $b$ (1933).

${ }^{2}$ Stebbing, T. R. R., "Amphipoda Gammaridea" in "Das Tierreich", 21, 390 (1906).

${ }^{3}$ Kunkel, B. W., Bull. Conn. State Geol. and Nat. Hist. Survey, 26, 94, Fig. 20 (1918).

'Weckel, A. L.,'Proc. U.S. Nat. Mus., 32, No. 1507, 32, Fig. 3 (1907)

5 Huntsman, A. G., "Contrib. Canad. Biol. 1911-14", part 2, 152 Fig. 4c (1915). 